6-1-1998

\title{
Feminism and the Public Sphere in Anne Brontë's The Tenant of Wildfell Hall
}

Rachel Carnell

Cleveland State University, r.carnell@csuohio.edu

Follow this and additional works at: https://engagedscholarship.csuohio.edu/cleng_facpub

Part of the Literature in English, British Isles Commons

How does access to this work benefit you? Let us know!

Publisher's Statement

Article originally published as Carnell, Rachel. K, "Feminism and the Public Sphere in Anne Brontë's The Tenant of Wildfell Hall," Nineteenth-Century Literature, Vol. 53, No. 1 (June 1998):

1-24. (C) 1998 by The University of California Press.

\section{Recommended Citation}

Carnell, Rachel, "Feminism and the Public Sphere in Anne Brontë's The Tenant of Wildfell Hall" (1998). English Faculty Publications. 25.

https://engagedscholarship.csuohio.edu/cleng_facpub/25

This Article is brought to you for free and open access by the English Department at EngagedScholarship@CSU. It has been accepted for inclusion in English Faculty Publications by an authorized administrator of EngagedScholarship@CSU. For more information, please contact library.es@csuohio.edu. 


\title{
Feminism and the Public Sphere in Anne Brontë's The Tenant of Wildfell Hall
}

\author{
RACHEL K. CARNELL
}

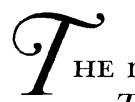

The Tenant of Wildfell Hall (1848) has

traditionally been criticized as a "clumsy" rupture in what might have been "a passionate and original love story." ${ }^{1}$ By embedding Helen Graham's diary into an extended letter between her second husband and his brother-in-law, Brontë has presumably prevented a more natural scene of seduction in which Helen could have gradually revealed her story to Gilbert Markham face to face. This somewhat awkward split narrative has recently been reappraised as not a defect after all but rather as a conscious commentary on the intractable cultural rift between public and private spheres. It is not surprising that critics who analyze Brontë's Tenant in these terms typically depend on a traditional definition of Victorian separate spheres, a definition that limits our understanding of Brontë's actual critique of the nineteenth-century public sphere.

Most recent critics who discuss Brontë's analysis of Victorian gender roles refer to the stereotypical distinction between a female domestic sphere and a male public sphere. N. M. Jacobs describes the narrative structure of The Tenant of Wildfell Hall as

(C) 1998 by The Regents of the University of California

1 Citing the above passage from George Moore, Conversations in Ebury Street (London: William Heinemann, 1930), p. 216 , Winifred Gérin employs the term "clumsy" in her introduction to the Penguin edition (see Anne Brontë, The Tenant of Wildfell Hall, ed. G. D. Hargreaves [Harmondsworth: Penguin, 1979], p. 13). 
one that "replicates a cultural split between male and female spheres that is shown to be at least one source of the tragedy at the center of the fictional world." ${ }^{2}$ Linda M. Shires ties this critique more broadly to representations of maenads, or monstrous women-images that were viewed with particular horror in the decades following the French Revolution. She concludes that the demonized representations of women, despite the horror they induced, brought a challenge to the traditional split between the separate spheres: "so increasing her influence and decreasing his in the public sphere." 3

In a somewhat related move, Elizabeth Langland sees Helen's narrative as transgressive, refuting the idea of "an essential female desire existing outside of and independent of the discursive practices that construct women's lives." 4 To see Helen's inner diary as subordinated to Gilbert Markham's outer frame thus indicates that our thinking "is already contaminated by the patriarchal ideology of prior and latter" (p. 111). As appealing as we may find such a Barthesian concept of transgressive narrativity, however, it is difficult to deny the fact that Anne Brontë did sandwich Helen's narrative within the confines of the correspondence between her husband and her brother-inlaw. We also need to recognize that viewing the narrative as a binary choice between patriarchalism and transgression-or even between public and private-situates the text within a peculiarly modern dichotomy.

We twentieth-century feminist critics are at a disadvantage in understanding Victorian modes of feminism or protofeminism because we have inherited a binary definition of gender roles that tends to simplify history. The very terms "public" and "private" have evolved dramatically in their usage and

\footnotetext{
2 "Gender and Layered Narrative in Wuthering Heights and The Tenant of Wildfell Hall," Journal of Narrative Technique, 16 (1986), 204.

${ }^{3}$ Linda M. Shires, "Of Maenads, Mothers, and Feminized Males: Victorian Readings of the French Revolution," in Rewriting the Victorians: Theory, History, and the Politics of Gender, ed. Shires (New York: Routledge, 1992), p. 157.

4 "The Voicing of Feminine Desire in Anne Brontë's The Tenant of Wildfell Hall," in Gender and Discourse in Victorian Literature and Art, ed. Antony H. Harrison and Beverly Taylor (DeKalb: Northern Illinois Univ. Press, 1992), p. 122.
} 
meaning over the past several hundred years, so that a simple binary retrospective-male means public, female means private - is not necessarily adequate to describe Brontë's project. In The Structural Transformation of the Public Sphere (1962) Jürgen Habermas suggests that there has always been a complex, contrapuntal relationship among the political realm, the public realm of debate and exchange, the private realm of economic exchange, and, finally, the domestic household. All of these realms are richly and symbolically interconnected, and their relationships to each other have never been stable or transhistorical but have evolved continuously from the mid seventeenth through the twentieth centuries. ${ }^{5}$ Habermas's analysis of the evolution of the terms "public" and "private" helps to illuminate the rich complexity of ideological threads that Brontë weaves into her bipartite but nonbinary narrative, even as her text helps to interrogate the ideal that Habermas describes.

Habermas analyzes, in particular, the eighteenth-century ideal of the public sphere: a meeting of minds in which men (and a few exceptional literary women) disregarded certain differences of rank or self-interest in order to discuss larger issues of the public good. According to Habermas's model, this consensual interest in the public good deteriorated by the mid nineteenth century as Luddite and Chartist uprisings challenged the narrow definition of "public" that had traditionally been intended by the educated, bourgeois men who had first described the public sphere. ${ }^{6}$ Although much has been made

${ }^{5}$ Susan Dwyer Amussen's excellent work on social and political systems in the sixteenth and seventeenth centuries supplements many of Habermas's claims about the historical relations between public and private. In explaining the assumed relation between family and state, typical of early modern thought, she explains: "At the very least, the analogy means that it is inappropriate to dismiss what happened in the family as 'private'; the dichotomy so familiar to us today between private and public is necessarily false when applied to the experience of early modern England" (Amussen, An Ordered Society: Gender and Class in Early Modern England [Oxford: Basil Blackwell, 1988], p. 2).

${ }^{6}$ See The Structural Transformation of the Public Sphere: An Inquiry into a Category of Bourgeois Society, trans. Thomas Burger (Cambridge, Mass.: MIT Press, 1989), p. 14 o. Much effort has been expended in attempting to demonstrate that the claims for the universality of the public sphere help to obscure that its major participants are propertied and male. For example, Michael Warner explains how "the bourgeois public sphere has been structured from the outset by a logic of abstraction that provides a 
of Brontë's challenge in Tenant to the rigid, gendered norms of the Victorian age, little has been made of her interest in the proper education of sons or in the cultivation of more rational debate among the landed bourgeois men who descend on the secluded country estates where most of the novel's action takes place. Brontë's interest in the public good does not preclude her interest in challenging the traditional separate spheres, but the novel's resolution ultimately concerns the good of the whole over the good of particular oppressed social groups, such as women. Beneath Brontë's concern about gender roles, I will argue, there lurks a reluctance to address the Chartist-influenced class challenges to an older version of the public good. In harkening back to an eighteenth-century model of the public sphere, Anne Brontë espouses not a twentieth-century-style challenge to the Victorian model of separate spheres, but a nineteenth-century-style nostalgia for the classical liberal model of bourgeois public debate. At the same time, however, the awkward rupture in Brontë's narrative represents the inherent contradictions between the different levels of discourse-literary, political, scientific-within the public sphere itself and the complex ways in which these levels are both accorded and denied cultural power.

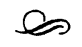

As Habermas explains, the original concept of rational public debate in Britain arose during the eighteenth century among educated men who gathered in coffee houses to critique government actions and protest against any perceived abuses of power. In this model, "private" does not mean "domestic" but rather the private economic individuals who

privilege for unmarked identities: the male, the white, the middle class, the normal" ("The Mass Public and the Mass Subject," in Habermas and the Public Sphere, ed. Craig Calhoun [Cambridge, Mass.: MIT Press, 1992], p. 383). While this analysis is certainly apt, it is also the case that Habermas fully acknowledges the male and bourgeois face of the public sphere: he specifically analyzes the exclusion of women from all but the literary public sphere (p. $5^{6}$ ), and he specifically addresses the narrow strata of bourgeoisie that was originally included in the idea of the public. His analysis of the fragmentation of the idea of the public as greater demands were made by the working class is an excellent case in point. 
banded together to protect common interests and who joined together regardless of relative distinctions of rank or wealth under the leveling concept of reason (see Structural Transformation, pp. 28-37). Reason became the grounding point for political opposition during the Enlightenment; however, the ability of rational men to connect with each other intellectually or politically depended not merely on their perception of each other as equally rational creatures but on their perception of shared humanism. We must consider, then, that as much as Brontë's novel is about the way patriarchal culture encourages men to become domestic tyrants, it is also about the fragile and frequently ruptured connection between Gilbert Markham and Frederick Lawrence, educated and propertied neighbors who cannot manage to find or sustain mutual trust. Although the inner narrative of Helen's diary provides an incisive critique of stereotypically male behavior (as Jacobs and Langland argue), Helen's story is nevertheless narratively enclosed within Markham's description of his efforts to reach a harmonious relationship with his two brothers-in-law, Lawrence and Halford. As much as we may like to interpret Helen's role as "focalizer" of the narrative (to use Langland's term), the novel in fact ends with Gilbert's final letter to Rose's husband, which includes an invitation to leave the city for a period of quiet peace and reflection at home.

At this point Helen's voice has dropped out of the narrative entirely. Although the estate where Helen and Gilbert live was brought to the marriage by her inheritance, Helen remains an invisible, humanizing backdrop to a pastoral or Shaftesburystyle interlude in which "toiling, striving" city men might visit the country to engage in philosophical dialogues about beauty or moral worth. Halford and Markham will continue to reflect on what has become Helen and Gilbert's familiar topic of conversation, "the promising young scions that are growing up about us," or the male future of the educated public sphere. ${ }^{7}$ Certainly we must acknowledge the possibility for transgressive

7 Anne Brontë, The Tenant of Wildfell Hall, ed. Herbert Rosengarten (Oxford: Clarendon Press, 1992), p. 498. Further references are to this edition and are included in the text. 
irony in this male-centered ending to a powerful woman's story, and yet we must remember that the proper raising of her son has always been one of Helen's main concerns: her unconventional attitude toward young Arthur's upbringing is partly what forces her to be an object of scrutiny from the time of her arrival at Wildfell Hall. To appreciate more fully Brontë's critique of the masculine public sphere, therefore, we must first clarify women's role in relation to it.

In Habermas's analysis the domestic sphere was not simply a separate female sphere defined in opposition to a public sphere of economic and political activity but also the humanizing linchpin on which both the private economic sphere and the public sphere of oppositional political debate relied. In Structural Transformation he describes

a public consisting of private persons whose autonomy based on ownership of private property wanted to see itself represented as such in the sphere of the bourgeois family and actualized inside the person as love, freedom, and cultivation - in a word, as humanity.

Of course, autonomy is designated for male property owners only; their wives and families provide the support and nurturing that humanizes them. As Habermas points out, "women and dependents were factually and legally excluded from the political public sphere" (p. 56). At the same time, however, there was a parallel sphere of literary discourse and debate in which, Habermas argues, "female readers as well as apprentices and servants often took a more active part ... than the owners of private property and family heads themselves" (p. $\left.5^{6}\right) .^{8}$ This

8 Of course, the participation of women as readers and occasionally as writers in the literary public sphere did not amount to any sort of universal ideal. After the Parliamentary Revolution of 1688, early English feminist writers Mary Astell and Margaret Cavendish, both staunch Tories, expressed serious reservations about the advantages to women of power being shared between men rather than concentrated in the single person of the king (see Catherine Gallagher, "Embracing the Absolute: The Politics of the Female Subject in Seventeenth-Century England," Genders, 1 [1988], 24-39; and Ruth Perry, "Mary Astell and the Feminist Critique of Possessive Individualism," EighteenthCentury Studies, 23 [199o], 444-57). Carole Pateman has likewise argued that the bourgeois public sphere depended on a perception that the household was separate from and irrelevant to political matters (see The Sexual Contract [Stanford: Stanford Univ. Press, 1988], p. 3). However, just as viewing the bourgeois as "homme" obscured his economic position of property owner, so woman's humanizing influence on the male 
so-called "literary public sphere," then, seems potentially to be the province of women: when he turns to Samuel Richardson as an ideal participant in the literary public sphere, Habermas codes him in traditionally feminine imagery (tears) as he describes how "Richardson wept over the actors in his novels as much as his readers did" (p. 5o). Casting the literary public sphere as potentially female, however, generates some confusion as to whether this sphere was perceived as an integral part of rational political debate or whether it was merely a tangential stepsister to a fraternal sphere of political discourse, responsible for humanizing the fraternity of brothers actively involved in public affairs.

Part of the difficulty in understanding Habermas's references to the literary public sphere is that he does not consistently develop or maintain the distinction between the literary and political public spheres in his analysis. ${ }^{9}$ Nor does he acknowledge the significant presence of female novelists in eighteenth-century Britain or their potential effect on the political weight of the literary realm. Yet writers such as Aphra Behn, Delarivier Manley, Eliza Haywood, and Mary Wollstonecraft, who wrote and openly published under their own names, certainly must be considered participants in the literary public sphere. As such, these eighteenth-century women may have felt slightly more welcome entering the Enlightenment public sphere than did Charlotte, Emily, and Anne Brontë when, a century later, they entered the more rigidly gendered publishing world under the pseudonyms Currer, Ellis, and Acton Bell. At the same time, however, even those eighteenth-century women who publicly dared to voice political opinions recognized themselves as exceptional, breaking rather than defining a norm. By defining themselves as exceptional women they managed to call attention to their difference as women even as they asserted the same rights as men to a public voice. For example, in the preface to her comedy The Lucky Chance (1686)

\footnotetext{
participants in public-sphere debates obscured her actual political disempowerment. The occasional and exceptionally literate woman might enter the realm of public debate through publication of novels or periodicals, further blurring most women's routine exclusion from the political public sphere.

9 See Elizabeth Heckendorn Cook, Epistolary Bodies: Gender and Genre in the EighteenthCentury Republic of Letters (Stanford: Stanford Univ. Press, 1996), p. 11.
} 
Aphra Behn protests against her work being judged by different standards than those applied to male playwrights simply because she is a woman. In her periodical The Female Spectator (1740-44) Eliza Haywood insists that her anecdotes of domestic life are more significantly political than legislative disputes, which she likens to "the Knots Children tye at School in Packthread." 10 Yet while she claims political relevance for amatory narratives otherwise coded as female, Haywood also warns in her $175^{6}$ conduct book The Wife that it was only the rare woman who would be rational enough and informed enough to overshadow her husband in debate: "there are so few women qualified to think on those affairs." "Haywood believes that even a well-informed and rational wife should guard against transgressing the "bounds of her own sphere: the unmarried, however, are at liberty to act as they please" (The Wife, p. 21). Although she does not necessarily invite every woman to participate in public political debate (as she herself attempts to do in her two periodicals), Haywood refuses to allow the public sphere to be defined through a wholly masculine paradigm.

Behn and Haywood insisted on the political import of their work by acknowledging themselves as women but gendering their literary talents as more rational than those of men. A century later, however, women's voices within the literary public sphere would not reflect so much confidence. While Behn and Haywood had insisted on a place for their female voices within an otherwise universally masculine paradigm for public discourse, Victorian women seemed to face the risk that in defining their voices as female they would be excluded altogether from public debate. The obsession in early critical reviews of the Brontës' work with the sex of the authors or with the appropriateness of the subject matter for female readers underscores the Victorian obsession with judging all behavior through a rigid lens of gender. ${ }^{12}$ Moreover, female authors in the nineteenth century did not demonstrate the same confidence as had their literary predecessors that they could maintain their

10 The Female Spectator, 4 vols. (London: T. Gardner, 1 745), II, 124.

11 The Wife (London: T. Gardner, 1756 ), p. 19.

12 See The Brontës: The Critical Heritage, ed. Miriam Allott (London: Routledge and Kegan Paul, 1974), pp. 249-65. 
identity as women while appropriating norms of male discourse in their literary endeavors. If they wanted to address questions of general political interest, Victorian women were encouraged to disguise their broad philosophizing with comments on particular details. Sarah Stickney Ellis explains in her 1843 conduct book The Wives of England: "The excellence of woman as regards her conversation, consists rather of quick, and delicate, and sometimes playful turns of thought." 13

Nancy Armstrong further elucidates the increasing rigidity of the nineteenth-century version of separate spheres by suggesting that the novel itself played a role in transforming other sorts of political difference, such as class difference, first into gender difference and then into personality difference: "As gender came to mark the most important difference among individuals, men were still men and women still women, of course, but the difference between male and female was understood in terms of their respective qualities of mind." ${ }^{14}$ For Armstrong, who analyzes the novels of Charlotte and Emily but not Anne Brontë, the Brontës' fiction turns "the materials of history into a representation of consciousness" (p. 204). Such an interpretation helps us to understand why gender difference came to be privileged above all other cultural differences by the nineteenth century and why it was so difficult for nineteenth-century women novelists to acknowledge the political implications of what they were doing. Armstrong's analysis of the two older Brontë sisters, however, does not fully explain the political critique implicit in Anne Brontë's fiction.

Inasmuch as her work fits into the dominant Victorian construction of gender difference, it makes sense that Anne Brontë would have made a fairly modest claim for what we perceive in retrospect as a daring novel: "if I have warned one rash youth from following in their steps, or prevented one thoughtless girl from falling into the very natural error of my heroine, the book has not been written in vain." ${ }^{15}$ Rather than asserting,

13 The Wives of England: Their Relative Duties, Domestic Influence, and Social Obligations (London: Fisher, Son, and Co., [1843]), p. 102.

${ }^{14}$ Desire and Domestic Fiction: A Political History of the Novel (New York: Oxford Univ. Press, 1987), p. 4 .

15 "Preface to the Second Edition" (Tenant, p. xxxviii). 
as did Eliza Haywood, that her particular domestic anecdotes are more political than a newspaper or periodical, Brontë claims merely that she speaks the truth with the modest hope of saving one soul. Brontë herself, therefore, seems to be following a Habermasian model of affective, nurturing humanism. Yet she allows her heroine, Helen Huntingdon, to speak out in the manner of the exceptional eighteenth-century woman writer and to make broad claims about nature, culture, and education: Helen thus emblemizes the rationality of the public sphere. Although Brontë skirts class issues that would threaten the unity of the public sphere, she does not translate political (or class) difference into gender difference as such but rather demonstrates how individual desires should be secondary to one's role as political creature concerned with the larger public good. Even if Helen Huntingdon describes "the unity of accordant thoughts and feelings" between herself and Markham (Tenant, p. $4^{87}$ ), her more central concern, after all, is how to raise her son into a model public citizen.

In her impassioned and articulate speeches against drinking, against boarding-school education, and against the irrational differences in the education of girls and boys, Helen Huntingdon enacts the sort of "talking on a large scale" that Victorian conduct books such as Sarah Ellis's The Wives of England would prohibit (p. 103). Helen's voice is rational, confident, and self-sufficient at this point in the narrative-and by the norms of the day, her discourse would certainly be deemed masculine. Furthermore, such issues also define the domain of the public good and concern the responsible rearing of future generations more than do most of the conversations between Markham and Lawrence. For example, when explaining why she has taught her son to detest the taste of wine, Helen suggests that she is speaking universally of men and of virtue:

"It is all very well to talk about noble resistance, and trials of virtue; but for fifty - or five hundred men that have yielded to temptation, shew me one that has had virtue to resist. And why should I take it for granted that my son will be one in a thousand? - and not rather prepare for the worst, and suppose he will be like ... the rest of mankind, unless I take care to prevent it?"

(pp. 27-28) 
Helen's "talking on a large scale" here about ways to render virtuous one man among five hundred is, in one respect, a modest claim for raising her own son. Her use of probability and numbers, however, broadens her assertion: if taken one by one, any one man - hence potentially the majority among five hundred-could eventually become more virtuous and more rational, the very qualities necessary to the ideal public citizen. Thus Helen's voice provides not merely a woman's humanizing influence on the male child she is raising but also a rational critique that belongs squarely in the discourses and debate of the bourgeois public sphere.

Through her position as a professional painter, Helen also participates, as an exceptional woman, in an aesthetic realm that serves an obvious parallel for the literary public sphere. Her impeccable taste is something that she and Gilbert share: they rarely discuss her paintings, but he immediately approves of them with a smile that indicates that they see eye-to-eye on the important matter of aesthetic judgment. And as such, according to eighteenth-century aesthetic theory, Helen was helping to promulgate the ideal of a shared appreciation of beauty, an ideal that exemplifies the eighteenth-century public sphere ideal of shared, universal (or educated) understanding, so crucial to Edmund Burke's ideal of universal understanding. ${ }^{16}$ Exceptionally literate and artistic, Helen challenges the separate gendered spheres by offering herself as one of the rare enlightened women who could claim a voice in public debate. Moreover, if we consider Helen as emblematically participating in the literary public sphere through her position as professional painter, we realize that this sphere was not merely a sphere of humanizing affect, as Habermas suggests, but in fact derived its cultural power from its rational and professional control of aesthetic mores. In this way, Brontë clearly understood-as her eighteenth-century literary predecessors, both male and fe-

16 Burke states that "it is probable that the standard both of reason and Taste is the same in all human creatures" (A Philosophical Enquiry into the Origin of our Ideas of the Sublime and Beautiful, 2d ed. [1759], ed. J. T. Boulton [London: Routledge and Kegan Paul, 1958], p. 1 1). See Terry Eagleton, The Ideology of the Aesthetic (Oxford: Basil Blackwell, 1990), for a useful discussion of the progressive and reactionary uses of this type of universalizing claim. 
male, knew quite well-that the literary public sphere located its cultural power in its simultaneous appropriation of both nurturing (traditionally female) imagery and rational (traditionally male) discourse. We return to Habermas's image of Richardson weeping over his own novels, and to Armstrong's assertion that "the modern individual was first and foremost a woman" (p. 8). But once the public sphere has defined itself as speaking in the voice of the rational yet empathetic male, how feasible was it for women to maintain their identities as women and continue to speak in a public voice? The nineteenth-century tendency for women writers to adopt male pseudonyms suggests the difficulty that women experienced in maintaining their separate identities as they introduced their texts into the public sphere: the disappearance of Helen Huntingdon's voice at the end of Brontë's novel only underscores the difficulty facing women who wanted to contribute to the public good.

Brontë struggles, as did Haywood, with the dilemma of whether participation in the public sphere is appropriate for all women or merely for some exceptionally rational women. Almost all of the other female characters in the novel prove that Helen's experience is not necessarily being touted as a universal model for women. Rose Markham, Eliza and Mary Millward, Milicent Hattersley, and Frederick's own mother are all described as pleasant and faithful but unable to speak rationally in philosophical terms. They are not denigrated for their adherence to traditional female roles, but it is clear that they will never transcend them. After Helen has intervened to resolve their marital misunderstanding, Milicent is described as joyful to be Hattersley's "happy little wife" (p. 466). Mary Millward happily gives up her status as old maid to marry a clergyman. Rose Markham, who once protests her mother's view that her role should be to make her brother's life more convenient and comfortable, presumably goes on to play just such a role for the man who will become Gilbert's primary confidant in telling his and Helen's story. Only the second wife of Lord Lowborough is granted the highest encomium of the rational public sphere, "genuine good sense" (p. 465), but unlike Helen, she is never seen discussing matters of art or taste; her talents are restricted to becoming "an excellent mother to the children, and an in- 
valuable wife to his lordship" (p. 465). Thus Brontë distances the literary public sphere from the traditionally female domestic sphere and so distinguishes literary women from ordinary women, focusing more on the difference between women rather than on the difference between a male and female voice in the public sphere.

Just as Mary Wollstonecraft struggles in A Vindication of the Rights of Woman (1792) between suggesting on the one hand that women need to be educated to perform their civic duty as rational wives and mothers and on the other hand that some women of the upper ranks might participate in aspects of professional life currently limited to men, ${ }^{17}$ so does Helen Huntingdon struggle at first between her position as professional painter and wage earner and her duty to raise her son to be a model citizen. Rather than promulgate Wollstonecraft's more radical social views, however, Brontë ultimately channels Helen's rational and aesthetic talents back to the household, where they will be used to humanize husband and son for the good of the public sphere. Giving up her career as a professional painter, Helen emblematically removes a woman's voice from the literary public sphere at a moment in history when previously universalizing discourses of reason were being challenged by both the working class and the increasingly specialized discourses of professional scientists. By silencing Helen at the end of the narrative, Brontë once again demonstrates her uncertainty as to whether the literary public sphere, which she clearly aligns with the (rationally) feminine, could be the province of ordinary women. In focusing on a woman whose ideas triumph at the cost of their being articulated through her husband's voice, Brontë suggests that the public good itself is more crucial than whether or not women receive due credit for contributing

17 Joan B. Landes describes Wollstonecraft as "shar[ing] the implicitly masculinist values of the bourgeois public sphere" (Women and the Public Sphere in the Age of the French Revolution [Ithaca: Cornell Univ. Press, 1988], p. 135). But Wollstonecraft also offers more radical possibilities for certain literate women. Compare, for example, the many chapters in $A$ Vindication in which she cajoles women to be more modest and virtuous and better educated for motherhood to her suggestions in chapter 9 that certain upperclass women might in fact enter business or the medical professions (see $A$ Vindication of the Rights of Woman, ed. Miriam Brody [Harmondsworth: Penguin, 1992], pp. 266-67). 
to it. And by ending the novel with Gilbert's voice rather than Helen's, Brontë draws our attention to the central, but critically overlooked, relationship between Gilbert Markham and Frederick Lawrence, a relationship that evokes an eighteenth-century model of rational discourse and humanistic exchange only through its marked failure to achieve either.

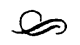

The outer layer of Brontë's narrative frame, Markham's letter to his brother-in-law, is an attempt to breach an emotional gap occasioned by Markham's earlier refusal to match Halford's narrative with a similar one of his own, a gap in the affective humanism that Habermas describes as essential to rational connection in the public sphere. Markham's recognition of this breach is described in purely affective terms in his description of Halford's disappointment: "your face was overshadowed with a cloud which darkened it to the end of our interview, and, for what I know, darkens it still" (p. 5). The outer narrative begins, therefore, with an acknowledgment of the importance of affective connection between property-owning men. And while much of the suspense of Markham's story derives from the mystery of Helen Graham, narrative interest is also built up around the complex relationship between Markham and Lawrence. Markham suggests to Halford that he and Lawrence are "on tolerably intimate terms," although he also indicates that the other man is "too cold, and shy, and selfcontained, to obtain my cordial sympathies" (p. 35). Lawrence apparently admires candor without coarseness, but he is too reserved to emulate it himself. Markham describes their "intimacy" as "rather a mutual predilection than a deep and solid friendship" (p. 36), such as he will later acknowledge between Halford and himself. According to an eighteenth-century Habermasian paradigm, these men should find much in common and should view each other as equal through their mutual rationality, despite Lawrence's somewhat more elevated wealth and status. But the link between Markham and Lawrence simply does not exist; one of the puzzles that the narrative explores 
is why two otherwise similar, rational men cannot manage to trust each other.

As Habermas would observe, without the trust or faith in another man's humanity a rational bond means little. We assume, according to Habermas's model, that the humanizing influence of a woman might help nurture such trust. Brontë shows, however, that one effect that women may have on men is to provoke their jealousy, rather than encouraging their humanism: Markham assumes that Lawrence is his rival for Helen Huntingdon's affections, and so he brutally and fiendishly attacks his friend with the metal end of a riding whip, nearly taking the other man's life. We may try to salvage Habermas's theory by suggesting that if not the influence of women as love objects, then the feminizing influence of the literary public sphere - in this case represented by Helen's diary — will enable men to cultivate enough humanism to bond rationally. Helen's diary seems to have so powerful an effect on Gilbert that, after reading it, he remembers his duty to apologize to Frederick Lawrence, even if the apology itself seems awkward and reluctantly given. Yet merely reading Helen's narrative does not suffice to reform Gilbert. While he treats Frederick Lawrence more appropriately after understanding Helen's story, Gilbert Markham still seems unable to forge a bond of friendship: he never becomes enough of a confidant for Lawrence to confide his own wedding plans to him; nor does Markham trust that his professed friend would actually encourage the union between himself and the more affluent Lawrence family. Brontë suggests, in other words, that the bond that Habermas envisions as an ideal - the bonding of men through humanistic reason despite slight differences in rank-does not occur by a mere act of reading.

Whereas the literary public sphere has a potentially humanizing influence, Brontë recognizes that literature in and of itself does not guarantee affective humanism. One of Gilbert's original impulses to attack Lawrence was that he had seen Lawrence's name written in a book in Helen's possession. Gilbert also tries to use the gift of Scott's Marmion to manipulate Helen into his favor; she must insist on purchasing it from him 
to deflect his ploy. As a consequence, books in the hands of men risk being employed in less than humanistic ways. To prevent the misuse of literature, it seems, women must first teach men how to read. Markham reads Helen's diary and at first assumes that her unhappiness with her husband legitimizes his own right to pursue her, thereby aligning him with the other men in her narrative who have similarly tried to abuse her vulnerable position. Helen herself is forced to explain to Gilbert that their mutual recognition of passion does not imply that they may consummate it but rather that they must forever part. Subsequently, on the verge of their engagement, when Helen hands Gilbert the fairly transparent emblem of her love, the Christmas rose, he proves an inept reader. He pauses at first, "absorbed in thinking what might be the meaning of her words" (p. 492). When she finally spells out to him what the rose represents, he still does not quite fathom that this is an invitation for him to propose to her. She at last has to prompt him by asking "Have I not said enough?" and softening her words "with a most enchanting smile" (p. 493).

This romantic denouement significantly revises that eighteenth-century novel of abduction that is most directly echoed by Helen's inner narrative of oppression and imprisonmentRichardson's Clarissa (1747-48). It is this particular text, the most tragic of Richardson's novels, to which Habermas probably refers when he describes the affective humanism generated by Richardson and his readers weeping together. ${ }^{18}$ Brontë, however, revises the notion that women must die tragically to generate feelings of humanity within the reading public. Instead, she suggests how women may inspire affective humanism through timely hermeneutic intervention. Helen escapes Clarissa's fate in part because she is able to teach Gilbert the one thing that Clarissa never manages to teach Lovelace: how to read his moral obligation from her narrative of distress. Accordingly, even as she demonstrates a certain romantic hope in the humanizing capacity of literature, Brontë underscores the need for women

18 For further analysis of the connection between literary and political public spheres in Richardson, see my "Clarissa's Treasonable Correspondence: Gender, Epistolary Politics, and the Public Sphere," Eighteenth-Century Fiction, 1 o (1998), 269-86. 
to be ever vigilant in instructing men how to read as enlightened humanists.

Gilbert Markham's somewhat uncertain capacity as reader casts doubt on Brontë's wisdom in having such an exceptionally rational woman as Helen Huntingdon renounce her professional position in order to become his wife. Helen will undoubtedly teach Gilbert and their sons to be rational and humane participants in the world of public affairs, but, having seen Helen's superior reason in action, readers may find it unfortunate that she must subordinate her role in the aesthetic public sphere in order to become helpmeet and nurturer of a husband and sons whose role in public life has yet to be proven. Then again, inasmuch as her husband and sons, unlike Helen herself, are endowed with the privileges of gender that will allow them full participation in the public realm of debate and critique, Helen does the greater public a favor by teaching these men to be more rational and insightful readers than they otherwise would be. Certainly the very fact that Markham manages to pen the extended letter to Halford that comprises the outer narrative of Brontë's novel indicates that over the years he has learned to nurture a bond of affective humanism with Rose's husband through rational, epistolary exchange, a bond such as was impossible for him to achieve with Frederick Lawrence in the period before Helen's affecting influence had taken its full effect. There is no doubt that Helen has improved her husband's ability to bond rationally and sensitively with other men and so, presumably, to be a better participant in the public sphere; however, she has done so through a traditionally feminine act of self-sacrifice.

By the end of the novel it is clear that Brontë does not envision a world in which the gendered norms of the separate spheres are radically altered; she concludes by making even the most literate of her female characters the helpmeet and nurturer of her husband, the provider of the rational humanism and sensitivity that will enable him to be a moral participant in the public sphere. Brontë also seems to accept without challenge that the public sphere should be bourgeois rather than more economically leveling. When Gilbert and Helen are finally reunited, Helen makes a plea for true love that perfectly mirrors 
a traditional public-sphere belief in the subordination of wealth to an ideal of affective humanism: "the greatest worldly distinctions and discrepancies of rank, birth, and fortune are as dust in the balance compared with the unity of accordant thoughts and feelings, and truly loving, sympathizing hearts and souls" (p. 494). For all the democratic appearances of this speech, however, we must remember that the differences in rank discussed here are only gradations within the landed, educated classes. Markham has already described himself to Halford not as an upstart but as a dutiful son of a property owner who has chosen to follow his deceased father's advice "and to transmit the paternal acres to my children in, at least, as flourishing a condition as he left them to me" (p. 7).

When, once he is married, Gilbert finally has the urge to share some of his vastly increased holdings, his impulse is to give the family farm to his brother, Fergus; never does any thought occur of sharing it with his sister or with any of the laboring families who actually work the soil. Yet it is not in his brother alone that Gilbert places his faith for the future, but also in the humanizing influence of Fergus's new love interest: "I bequeathed the farm to Fergus, with better hopes of its prosperity than I should have had a year ago . . . for he had lately fallen in love with the vicar of L_-'s eldest daughter" (p. 497). Brontë thus concludes the novel by reinforcing the humanizing ideal of a woman's influence on men as well as the ideal of the benevolent, rational landlord, crucial to the stability of the bourgeois public sphere. At a moment in history when the rational, bourgeois sphere was beginning to be challenged by the demands of the working class and women for inclusion within the public realm of rational debate, Brontë seems to accept the class-based and gender-based norms of the Enlightenment public sphere. The ambivalence of her bipartite narrative, similar to the ambivalence evident in the oddly mythic final paragraphs of Charlotte Brontë's Shirley (1849), marks Anne Brontë's reluctance to repudiate the educated, bourgeois sphere in which she was raised. ${ }^{19}$

\footnotetext{
19 Susan Zlotnick explains how Charlotte Brontë "places her own 'private judgment,' her sense of what a happy ending is - the progress of industrial capitalism - in a nostalgic narrative that laments change while, at the same time, she embeds the text's real
} 
This is not to suggest that, according to some ex-post-facto paradigm of progressive ideology, Brontë should have written her novel differently. But if we are to understand how her ideas fit into the evolution of feminist thought, we need to put her novel into an appropriate historical context. Linda M. Shires argues that we need to place Brontë into a historical continuum of feminist thinking: somewhere after Wollstonecraft, whose ideas she would have viewed with unease, but before the "revitalized English feminism" of the 185 os, which Shires describes as "just around the corner" (p. 162). It is difficult to be certain exactly what Brontë derived from Wollstonecraft-whose works she would not necessarily have read, although she certainly shared her interest in rational feminism ${ }^{20}$ _ or what she contributed to the next wave of feminists, presumably including Harriet Taylor Mill (although Shires never specifies particular names). Unlike Mary Wollstonecraft (writing in 1792), Brontë never suggests a parallel between the idle rich and mentally idle women. ${ }^{21}$ Unlike Mill (writing in $185^{1}$ ), Brontë articulates no parallel between class movements and the women's movement, nor does she demand anything like suffrage for women..$^{22}$ In "Enfranchisement of Women" Mill herself in fact casts doubt on the feminist credentials of her contemporary female novelists when she inveighs against "the literary class of women ... [who] are ostentatious in disclaiming the desire for equality or citizenship" (p. 119).

Obviously the example of Helen Huntingdon as exceptional woman provides a powerful example of independence and autonomy, and yet it is misleading merely to place Anne

tragedy - the lack of progress - in a traditional happy ending of love and marriage" ("Luddism, Medievalism and Women's History in Shirley: Charlotte Brontë's Revisionist Tactics," Novel, 24 [1991], 294).

${ }^{20}$ See Elizabeth Langland, Anne Brontë: The Other One (Totowa, N.J.: Barnes and Noble, 1989), p. 39 .

${ }^{21}$ Wollstonecraft sets up the parallel in comments such as: "it is in the most polished society that noisome reptiles and venomous serpents lurk under the rank herbage; and there is voluptuousness pampered by the still sultry air, which relaxes every good disposition before it ripens into virtue" (A Vindication, p. 257).

22 Mill writes, for example: "The Chartist who denies the suffrage to women, is a Chartist only because he is not a lord" ("Enfranchisement of Women" [1851], in John Stuart Mill and Harriet Taylor Mill, Essays on Sex Equality, ed. Alice S. Rossi [Chicago: Univ. of Chicago Press, 197o], pp. 96-97). 
Brontë within some artificial continuum of emergent feminists, as if these voices existed in isolation from attitudes toward liberal political theory and the public sphere. Rather than demand a separate platform of rights for women, Brontë ultimately sought wholeness and integration between the sexes through an eighteenth-century ideal of the public good in which most women might participate indirectly as instructors and nurturers of their husbands and sons. Through the example of Helen Huntingdon, Brontë shows us how women might need to give up their own direct participation in the literary (or aesthetic) public sphere in order to help the men in their lives learn to participate more effectively in the broader political public sphere, even as the abrupt silencing of Helen's voice serves to remind us of the self-sacrifice that women may have had to make in order to help men to achieve the mythic paradigm of universal sympathy and rationality. Brontë offers this vision just at a moment when the natural wholeness or universality of the eighteenth-century conception of the public sphere was radically being called into question, following the French Revolution and the years of labor unrest in the early nineteenth century.

\section{e}

Even as the educated bourgeois and landed classes were working out their vision of shared humanity, focusing on the presumably universalizing power of reason and the humanizing power of affective humanism, other segments of the population were also beginning to articulate their own version of rational humanism. E. P. Thompson insists that by 1820 it would have been a mistake to see "a single, undifferentiated 'reading public'"; instead he describes "several different "publics," including "the commercial public," other "more-orless organised publics, around the Churches or the Mechanic's Institutes," and then "the active, Radical public," which was starting to organize its demands for workers' rights. ${ }^{23}$ Although Habermas does not refer specifically to these alternative public

${ }^{23}$ The Making of the English Working Class (New York: Random House, 1963), p. 719. 
spheres, he does describe a shift in the different conception of citizen and humanity that emerged in Britain by the 1830 s and 184 os, in which the idea of the public came to suggest a broader segment of the population. In this mid-nineteenthcentury movement of expanding demands for suffrage and workers' rights even liberal thinkers such as John Stuart Mill, spouse of Harriet Taylor, would refer to the "yoke of public opinion" rather than the power of rational opposition inherent in public debate (quoted in Habermas, p. 133). Habermas explains how the eighteenth-century "model of a public sphere... claimed the convergence of public opinion with reason ... to be objectively possible (through reliance on an order of nature or, what amounted to the same, an organization of society strictly oriented to the general interest)" (pp. 130-31). By the mid nineteenth century

The public was expanded, informally at first, by the proliferation of press and propaganda; along with its social exclusiveness it also lost the coherence afforded by the institutions of sociability and a relatively high level of education. Conflicts hitherto pushed aside into the private sphere now emerged in public.... Laws passed under the "pressure of the street" could hardly be understood any longer as embodying the reasonable consensus of publicly debating private persons. They corresponded more or less overtly to the compromise between competing private interests. (pp. 131-32)

By the 184 os the old-boys' club of rational debate between bourgeois men was ruptured; the masses of the public, with their economic and political demands-including those of the Luddites and the Chartists - changed the shape of public opposition forever.

An aspect of the evolving public sphere or spheres to which neither Thompson nor Habermas refers is the increasing tendency to use a specific subcategory of reason-scientific expertise - to create a hierarchy among rational, educated persons just at the moment when broader segments of the population were beginning to claim their rational voice. Judith Newton describes how during the 183 os and 184 os "scientific organizations such as the Royal Society, the Statistical Society, and the 
Political Economy Club ... helped establish the social value of a specific expertise." Newton pointedly observes that once feminists such as Mary Wollstonecraft and Harriet Martineau had claimed the category of "rational individual" for women as well as men, periodical writers increasingly ceded cultural authority to a more exclusive category, "that pertaining to "men of science." "24

Newton's analysis helps us to understand that even as Anne Brontë was participating in a tradition of rational debate about the larger public good, her position as female novelist was diminishing in cultural authority vis-à-vis more scientifically trained writers. Her decision to have her heroine become a professional painter accords the inner narrative some of the cultural authority of a professional, albeit not that of a scientist. The language of Brontë's preface to the second edition of the novel, however, employs a certain discourse of scientific authority. She describes her aim as not "to ingratiate myself with the Press and the Public" but rather "to tell the truth" (p. xxxvii). Here the word "truth" is accorded a moral significance for "those who are able to receive it," yet her language simultaneously echoes the scientific impulse of separating truth from superstition as well as the utilitarian impulse of putting her own talents "to their greatest use" (p. xxxix) as she endeavors to benefit the greater "Public" in her hopes of steering even "one rash youth" (p. xxxviii) from following the path of error and alcoholism. However, to suggest that Brontë ever intended to privilege professionalism or utilitarianism over traditional Christian morality would be to misunderstand her insistence that whatever truth she tells will be effected by "the help of God" (p. xxxix). Her religious faith, then, becomes part of her impulse for integrating the idea of the greater public good with the wholeness of humanity.

Insofar as Helen's diary identifies her with the pragmatic and the professional, the disappearance of Helen's voice by the end of Gilbert Markham's concluding section suggests Brontë's reluctance to challenge the wholeness of the public sphere by

${ }^{24}$ Judith Newton, "Engendering History for the Middle Class: Sex and Political Economy in the Edinburgh Review," in Rewriting the Victorians, p. 7. 
the potentially fragmenting influence of either scientists, professionals, women, or the lower classes. Helen represents a woman who, within the confines of her inner narrative, refuses the gender role dictated to her by her culture, insists on her status as a professional painter, pursues an affective and humanistic bond between herself and her loyal servant Rachel, and challenges the economic subordination of wives. And yet, rather than allow Helen to transgress fully the bounds of the status quo, Brontë has her heroine turn from the cacophony of an increasingly fragmented public discourse to a nostalgic vision of domestic harmony within the Enlightenment public sphere. It is possible to argue that the final suppression of Helen's voice marks the underlying tragedy behind the romantic conclusion of the novel, but it would be implausible to claim that Brontë intended her poignant denouement-in which Gilbert must once again learn from Helen the power of humility so necessary to the wholeness of affective humanism - as merely ironic. Brontë, of course, does challenge marriage laws and cultural injunctions that require a woman to stay with an abusive husband, just as she criticizes the norms of the separate spheres that prevent women from raising their male children virtuously. And yet, the overall criticism of society effected by her bipartite narrative concerns the loss of such rational exchange and debate that once defined the ideal of public good-and (theoretically at least) allowed men and women to work together, in their separate spheres, for the good of the family, the state, and the country. Brontë challenges the Victorian gender roles but only within a nostalgic plea to return to the Enlightenment ideal of the public sphere.

Given that many feminists today have not yet determined whether it is more to women's advantage to press for special rights based on difference or to continue to have faith in the sameness claims of classical liberalism, we need not blame Anne Brontë for her double-edged message to women. ${ }^{25}$ As tempting as it is to privilege the "clumsy" inner narrative that George

25 Compare the general strategies of, for example, Catharine A. MacKinnon in Toward a Feminist Theory of the State (Cambridge, Mass.: Harvard Univ. Press, 1989), and Elizabeth Fox-Genovese in Feminism Without Illusions: A Critique of Individualism (Chapel Hill: Univ. of North Carolina Press, 1991). 
Moore so wished had been turned into a romantic dialogue, it ultimately remains impossible to determine whether it is Helen or her future husband who claims the most powerful narrative position. And yet it is precisely through this structural indeterminacy that Brontë articulates the struggle between men and women as they mutually seek the public good. Refusing both the sameness of parallel experiences and the difference of separate interests, Brontë weaves a bipartite narrative whose center neither wholly cleaves nor wholly holds.

Cleveland State University 